https://doi.org/10.30910/turkjans.680096

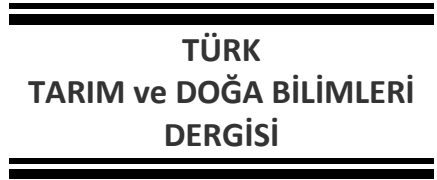

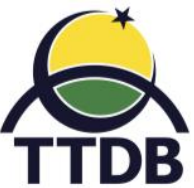

www.dergipark.gov.tr/turkjans

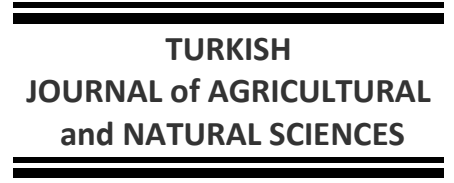

Araştırma Makalesi

\title{
Muş i̇lindeki Kaz Yetiştiriciliğinin Genel Yapısı ve Sorunları ${ }^{\S}$
}

\author{
Turgay ŞENGÜL ${ }^{1 *}$, İsmail YETER ${ }^{2}$ \\ ${ }^{1}$ Bingöl Üniversitesi Ziraat Fakültesi Zootekni Bölümü, Bingöl \\ ${ }^{2}$ Bingöl Üniversitesi Fen Bilimleri Enstitüsü, Bingöl \\ *Sorumlu yazar: tsengul2001@yahoo.com
}

Geliş Tarihi: 11.11.2019

Düzeltme Geliş Tarihi: 09.01.2020

Kabul Tarihi: 09.01.2020

\section{Özet}

Bu çalışma, Muş ilinde ekstansif ve yarı entansif şartlarda yapılan kaz yetiştiriciliğin mevcut durumunun ortaya konulması ve yetiştiricilikte karşılaşılan önemli sorunların tespit edilmesi amacıyla yapılmıştır. Çalışmanın materyalini, Muş ili merkez, Hasköy, Bulanık, Malazgirt, Varto ve Korkut ilçelerine bağlı ve kaz yetiştiriciliğinin yoğun olarak yapıldığı köylerdeki 105 adet kaz üreticisinden elde edilen veriler oluşturmuştur. Araştırma bulgularına göre; Muş ilinde, üreticilerin hiçbirinin kaz yetiştiriciliği konusunda eğitim almadığı ve yetiştiricilik yapma sürelerinin ortalama 17 yıl olduğu belirlenmiştir. İşletme başına damızlık dişi kaz sayısının ortalama 18 adet, damızlık erkek kaz sayısının ise 8 adet olduğu saptanmıştır. Kaz barınaklarının büyüklüğünün ortalama 50 $\mathrm{m}^{2}$ olduğu ve genellikle briket malzemeden yapıldığı belirlenmiştir. Kazların genellikle 4 haftalık yaşta iken meraya çıkarıldığı ve günde 2 kez yemlendiği saptanmıştır. Yetiştiricilerin \%67'sinin hastalıklara karşı hiçbir önlem almadığı, \%30'unun vitamin, ilaç vb. kullandığı, \%3'ünün ise aşı yaptırdığı belirlenmiştir. Sonuç olarak; Muş ilinde yapılan kaz yetiştiriciliğinin yapısı ve sorunlarının ülke geneli ile benzer olduğu ve üretimin daha çok ailenin et ihtiyacını karşılamak amacıyla yapıldığı saptanmıştır. Üreticilerin başta gelen sorunlarının; eğitim yetersizliği, hastalıklar, kullanılan düşük verimli ırklar, bakım-besleme konusundaki yetersizlikler ve pazarlamada karşılaşılan sorunlar olduğu söylenilebilir.

Anahtar kelimeler: Muş, kaz yetiştiriciliği, üretici, bakım-besleme, hastalıklar, pazarlama.

\section{General Structure and Problems of Goose Production in Muş Province}

\begin{abstract}
This study aims to determine the current situation of goose breeding in Muş province under extensive and semi-intensive conditions and to identify important problems encountered. The material of the study consists of data obtained from 105 goose breeders from the villages located in Merkez (Central), Hasköy, Bulanık, Malazgirt, Varto, and Korkut districts, where intensive goose breeding is being carried out, in Muş Province. According to the findings of the research, it was determined that none of the breeders received training on goose breeding in Muş province and the average duration of breeding was 17 years. It is determined that the average number of female breeder geese per farm was 18 and male breeder geese per farm was 8 . The average size of the geese enclosures was $50 \mathrm{~m}^{2}$ and they were generally made of briquettes. It was found that geese were generally taken out to the pasture at the age of 4 weeks and fed twice a day. It was determined that $67 \%$ of breeders did not take any precautions against diseases, 30\% used vitamins, medicines, etc., and $3 \%$ vaccinated the animals. As a result, it was determined that the structure and problems of goose production in Muş province were similar to the rest of Turkey and the production was mostly made to supply the meat needs of the family. It can be stated that the main problems of the breeders are inadequacy in education, diseases, low-yield breeds, inadequate management and feeding, and marketing problems.
\end{abstract}

Key words: Muş, goose production, producer, management-feeding, diseases, marketing. 
Giriş

Kanatlı etlerinin ucuz üretim maliyetli protein kaynağı olmalarından dolayı hayvansal protein ihtiyacının karşılanmasında önemli bir payı vardır. Kanatlı eti denildiğinde, ilk akla gelen ve en büyük paya sahip olan tavuk eti olsa da, hindi, kaz ve ördek gibi diğer kanatlı etlerinin de insanların beslenmesindeki yeri önemlidir. Kaz yetiştiriciliği, tüm dünyada üretim düzeyi açısından diğer kanatlılar arasında en son sıralarda yer almaktadır. Bunun en önemli nedenleri, kaz ürünlerine olan talebin düşüklüğü, kazın sıcak- kurak iklimlere uygun olmaması ve kazların üreme yeteneklerinin diğer kanatlılara oranla daha sınırlı olmasıdır. Dünyada, toplam kanatlı eti üretimi içindeki kaz ve ördek eti payının \%4 olduğu ve bu oranın gelişmekte olan ülkelerde \%9.8'e kadar çıktığı bildirilmiştir (Aksoy ve Arıkan, 1995). Ancak, son yıllarda, özellikle ülkemizde kaz ürünlerine olan ilginin değiştiği ve kaz etine olan talebin hızla arttığı görülmektedir. Kaz yetiştiriciliğine olan ilgiyi arttıran etmenler olarak; tüketicilerin alternatif lezzet arayışı, kırsal alanlarda yetiştirilmesi nedeniyle kaz etinin daha sağlıklı ve güvenilir bulunması, kaz yetiştiriciliğinin organik üretime uygun olması ve kırsal kalkınmaya sağladığı yararlar sayılabilir (CywaBenko ve ark., 1999; Çelik ve Bozkurt 2009). Ayrıca, kazların otlama kabiliyetlerinin iyi oluşu, yabancı otları tüketebilmeleri, zor şartlara ve hastalıklara dayanıklı olmaları yanında besi performanslarının da yüksek olması yetiştiriciler açısından tercih sebebidir (Labatut, 2002). Bu nedenle, kaz etinin, gelecekte protein kaynağı olarak tavuk etine önemli bir alternatif olabileceği söylenilebilir. Kaz yetiştiriciliği, daha çok soğuk iklimlere sahip ve su kaynaklarının bol olduğu ülkelerde ve bölgelerde yapılmaktadır. Özellikle, Güneydoğu Asya ve Doğu Avrupa ülkelerinde kaz ve ördek eti üretimi büyük öneme sahiptir (Çelebi, 1999; Çelik, 2007). Kaz yetiştiriciliği bakımından, Çin, Rusya, Mısır, Romanya, Ukrayna, Polonya, Madagaskar ve Macaristan önde gelen ülkeler arasındadır. Bu ülkelerin çoğunda kazlar, kaz eti, kaz ciğeri ve kaz tüyü elde etmek amacıyla yetiştirilmektedir. Kazlardan elde edilen verimler arasında et üretimi en başta gelse de, kaz yetiştirme amaçları ülkelere göre farklılıklar gösterebilmektedir. Bazı ülkelerde kaz ciğeri veya kaz tüyü üretimi daha ön planda olabilmektedir.

Sahip olduğu iklim ve su kaynakları açısından değerlendirildiğinde, kaz yetiştiriciliği açısından ülkemizin önemli bir potansiyele sahip olduğu söylenilebilir. 2018 yılı itibariyle ülkemizde kaz varlığının 1.080.190 adet olduğu bildirilmiştir (TÜiK, 2018). Türkiye'de kaz yetiştiriciliği, Doğu ve Orta Anadolu ile İç Ege bölgeleri başta olmak üzere hemen hemen tüm bölgelerde ve genellikle ekstansif şartlarda yapılmaktadır. Kaz yetiştiriciliğinin en yoğun olarak yapıldığı üç il sırasıyla, Kars, Ardahan ve Muş'tur. Kaz yetiştiriciliği, ülkemizde, özellikle üretim maliyetlerinin düşüklüğü ön planda tutularak, daha çok kırsal alanlarda ve geleneksel olarak sürdürülmektedir (Boz ve ark., 2014; Taşkın ve ark., 2017). Kaz yetiştiriciliği, ülkemizde daha çok ailelerin et ihtiyaçlarını karşılamaya yönelik olarak yapılmaktadır. Bu nedenle, kaz etinin, kırsal kesimde yaşayan tüketiciler açısından önemli bir protein kaynağı olduğu söylenilebilir.

$\mathrm{Bu}$ çalışmanın Muş'ta yürütülmesinin nedeni, bu ilin ülkemizde kaz yetiştiriciliği açısından önde gelen illerden biri olmasıdır. Muş ilindeki yaklaşık 660.000 adet toplam kanatlı hayvan varlığının yaklaşık \%17'sini kazlar oluşturmaktadır. $\mathrm{Bu}$ oran, diğer illerle karşılaştırıldığında oldukça yüksektir. Van, Muş, Bitlis ve Hakkâri illerinden oluşan TRB2 Bölgesindeki 2018 yılındaki toplam kaz sayısı 102.141 adet olarak belirlenmiş olup, Muş ilinin bölge içindeki payı yaklaşık olarak \%91 oranındadır. TRB2 bölgesinin Türkiye genelindeki payı ise, \%9.5 civarındadır. Muş'ta, tarım ve hayvancılığa dayalı bir üretim yapısının olması, iklimin soğuk, rakımın yüksek, su kaynaklarının bol ve aile tipi kanatlı yetiştiriciliği için kazın uygun bir tür olması, bu ilde kaz yetiştiriciliğini geleneksel hale getirmiştir. Muş ve ilçelerindeki kırsal alanlarda üretilen kazların etleri, kış aylarında ailelerin et ihtiyaçlarının bir kısmını karşılamakta ve aile fertleri tarafından severek tüketilmektedir. Muş ilinde yapılan kaz yetiştiriciliği, özellikle Malazgirt ve Bulanık ilçelerinde yoğunlaşmıştır.

$\mathrm{Bu}$ çalışmada, ülkemizde kaz yetiştiriciliği bakımından ilk sıralarda yer alan Muş ili ve ilçelerindeki kaz üretimiyle ilgili mevcut uygulamaların ve sorunların belirlenmesi ve bu sorunlara çözüm getirilmesi amaçlanmıştır.

\section{Materyal ve Yöntem}

Çalışmanın materyalini, Muş iline bağıı Merkez, Hasköy, Bulanık, Malazgirt, Varto ve Korkut ilçelerine bağlı, kaz yetiştiriciliğinin yoğun olarak yapıldığı köylerdeki kaz üreticileri ile yapılan anket verileri oluşturmuştur. İldeki kaz yetiştiriciliğinin mevcut durumunun belirlenmesi amacıyla 40 adet sorudan oluşan anket formları hazırlanmıştır. Muş ili merkez ve ilçelerinde toplam 105 adet işletme ile anket yapılması planlanmış ve söz konusu işletmelere gidilerek birebir görüşmelerle anketler doldurulmuştur. Merkez ilçede 48, Hasköy'de 7, Bulanık'ta 20, Malazgirt'te 18, Varto'da 5 ve Korkut'ta 7 adet işletmede anket yapılmıştır.

Çalışmada, üreticilerin sosyo-demografik özellikleri ile kaz varlığı, bakım-besleme uygulamaları, kaz barınaklarının durumu, ekipman 
kullanımı, sağlık koruma ve hastalıklar, pazarlama vb. konular araştırılmıştır. Çalışmanın örnek hacmi belirlenirken, ana kütle oranlarına dayalı gruplandırılmamış tek aşamalı rastgele olasılık örnekleme yöntemi kullanılmıştır. Örnek büyüklügünün belirlenmesinde aşağıdaki formülden yararlanılmıştır (Karasar, 1994).

Burada;

$$
n=\left(z^{2 *} N^{*} p^{*} q\right) /\left(N^{*} d^{2}+z^{2 *} p^{*} q\right)
$$

$\mathrm{n}$ : Örnek hacmi

z: \% 95 önem derecesine karşılık gelen z çizelge değeri

$\mathrm{N}$ : Ana kütle sayısı

p: Incelenen olayın ana kitle içinde gerçekleşme olasılığı \%50 olarak alınmıştır.

q: İncelenen olayın gerçekleşmeme olasılığı

d: Kabul edilen hata payı (Bu çalışmada hata payı \%5 olarak alınmıştır).

Çalışmanın verileri SPSS 17.0 paket programında değerlendirilmiş, tanımlayıcı istatistikler ve yüzde değerler olarak ifade edilmiştir.

\section{Bulgular ve Tartışma}

\section{Yetiştiricilerin sosyo-demografik özellikleri}

Yapılan anket sonuçlarına göre, yetiştiricilerin \%42.8'inin 40 yaşından küçük olduğu, $\% 30.5^{\prime}$ inin $41-50$ yaş arasında olduğu ve \%26.7'sinin ise 50 yaş ve üstünde olduğu belirlenmiştir. Yetiştiricilerin yaşlarının 28 ile 65 arasında değiştiği ve ortalama 43.8 olduğu tespit edilmiştir. Demir ve ark., (2013) Ardahan'da yaptıkları çalışmada, yetiştiricilerin ortalama 41.9 yaşında olduğunu belirlemişlerdir. Boz ve ark., (2014) ise, yapmış oldukları çalışmada, yetiştiricilerin \%58'inin 40-59; \%23'ünün 20-39 yaşları arasında olduğunu bildirmişlerdir.

Yetiştiricilerin eğitim durumlarına bakıldığında, okuryazar olan yetiştirici oranının $\% 9.5$, ilkokul mezunu olanların \%35.2, ortaokul mezunu olanların \%54.3 ve lise mezunu olanların oranı \%1 olarak tespit edilmiştir. Demir ve ark., (2013) Ardahan'da yaptıkları çalışmada, yetiştiricilerin \%79'unun (\%4 okuma yazma bilmeyen, \%75 ilkokul mezunu) eğitim düzeyinin düşük olduğunu belirlemişlerdir. Boz ve ark., (2014) tarafından Yozgat'ta yapılan çalışmada, yetiştiricilerin \%15.5'inin okuryazar olmadı̆̆ı, \%40'ının ilkokul, \%35.5'inin ortaokul ve \%9'unun lise mezunu olduğu saptanmıştır. Yetiştiricilerin aylık gelirlerinin ortalama 888.1 TL olduğu belirlenirken, aylık geliri $500 \mathrm{TL}$ ve altında olan yetiştirici oranı \%16.1, 501-1000 TL arasında olan yetiştirici oranı \%34.2 ve $1000 \mathrm{TL}$ ve üstünde olan yetiştirici oranı ise \%49.7 olarak saptanmıştır.
Yetiştiricilerin kaz yetiştiriciliği yapma süresinin ortalama $17 \mathrm{yıl}$ olduğu belirlenirken, $\% 44.7$ 'sinin 10-20 yıl arasında, \%38.2'sinin 20 yıl ve üstünde, \%17.1'inin ise 10 yıldan az süreyle kaz yetiştiriciliği yaptığı saptanmıştır. Ardahan'da yapılan bir çalışmada, kaz yetiştiriciliği yapma süresi ortalama 18.6 yıl olarak tespit edilmiştir (Demir ve ark., 2013). Boz ve ark., (2014) yürüttükleri bir çalışmada, yetiştiricilerin büyük bir kısmının (\%48) kaz yetiştiriciliği yapma süresini 10 yıldan az olarak tespit etmişlerdir.

Üreticilerin, kaz yetiştiriciliği konusunda herhangi bir eğitim alıp almadıklarıyla ilgili sorulara verdikleri cevaplardan, hiçbir üreticinin konuyla ilgili eğitim almadığı sonucu ortaya çıkmıştır.

\section{Kaz yetiştiriciliğinin amacı ve üretim yapısı}

Anket sonuçlarına göre, Muş ilindeki üreticilerin $\% 64$ 'ünün ailenin et ihtiyacını karşılamak, \%11'inin gelir elde etmek ve \%25'inin ise hem ailenin et ihtiyacı hem de gelir elde etmek için kaz yetiştiriciliği yaptıkları belirlenmiştir. Kaz yetiştirme amacının ilçeler itibariyle farklılık gösterdiği belirlenirken, Korkut ilçesindeki tüm yetiştiricilerin et ihtiyacı için bu işi yaptıkları saptanmıştır. Kaz yetiştiriciliğini gelir elde etmek için yapan yetiştiricilerin genel olarak Merkez ilçe ve Malazgirt ilçelerinde yoğunlaştığı gözlenmiştir. Demir ve ark., (2013) tarafından Ardahan'da yapılan bir çalışmada, kaz yetiştiriciliğinin öncelikli olarak et ihtiyacı için yapıldığı, ayrıca kaz etinin yetiştiricilerin \%79.3'ü için önemli bir geçim kaynağı olduğu bildirilmiştir. Aygün ve Akbulak (2017) tarafından Ardahan'da yapılan diğer bir çalışmada da, kaz yetiştiriciliğinin büyük ölçüde ailenin et ihtiyacı için yapıldığı, kaz etinin çok az bir kısmının ise yerel pazarlarda satılarak gelir elde edildiği bildirilmiştir. Yozgat ilinde yapılan bir çalışmada, ailelerin \%85.5'inin kaz yetiştiriciliğini tüketim alışkanlığı ve kendi ihtiyaçlarını karşılamak amacıyla yaptıkları belirlenmiştir (Boz ve ark., 2014).

Palaz intiyacını satın alarak karşılayan yetiştiricilerin oranı $\% 53$, doğal kuluçka yoluyla üretenlerin oranı $\% 26$ ve her iki şekilde karşılayanların oranı ise \%21 olarak bulunmuştur. Boz ve ark., (2014) tarafından yürütülen bir çalışmada, üreticilerin palaz teminini genellikle doğal kuluçka ile sağladığı, çok bir kısmının ise palaz satın aldığı belirlenmiştir.

Yetiştiricilerin ortalama olarak 14.7 adet palaz satın aldıkları belirlenirken, satın alınan palazların \%62'sinin 2 haftalık yaşta, \%21'inin 3 haftalık yaşta ve \%17'sinin ise 3 haftalık yaştan büyük olduğu belirlenmiştir. Yetiştiricilerin kaz palazını ortalama 36.2 TL/adet 'ten satın aldıkları saptanmıştır. Palazları, Nisan ayında kuluçkadan çıkaran veya satın alan yetiştiricilerin oranı $\% 58$, 
Mart ayında kuluçkadan çıkaran veya satın alan yetiştiricilerin oranı \%26, Mayıs ayında kuluçkadan çıkaran veya satın alan yetiştiricilerin oranı \%13 ve Şubat ayında kuluçkadan çıkaran veya satın alan yetiştiricilerin oranı ise \%3 olarak bulunmuştur. Yetiştiricilerin, sahip oldukları kazları satışa kadar ortalama 30 hafta süreyle besledikleri ve palaz ölümlerinin genellikle 0-7 günler arasında gerçekleştiği belirlenmiştir.

Sahip olunan dişi kaz sayısı ortalaması, Muş ili genelinde 18 adet olarak bulunurken, Merkez ilçede 23 adet ile en yüksek, Hasköy ilçesinde ise 10 adet ile en düşük sayı belirlenmiştir. Erkek kaz sayısı ise, ortalama 11 adet ile en yüksek Malazgirt ilçesinde görülürken, en düşük değer 2 adet ile Korkut ilçesinde saptanmıştır. Muş ili genelinde erkek damızlık kaz sayısı ortalama 8 adet olarak belirlenmiştir. Erkek ve dişi damızlık kaz sayılarına ait ortalamalar arasındaki farklılıklar ilçeler itibariyle değişiklik göstermiş ve ortalamalar arasındaki farklılıklar istatistiki olarak önemli $(P<0.05, P<0.01)$ bulunmuştur. Yetiştiriciler, dişi damızlıkları ortalama 2.4 yıl, erkek damızlıkları ise ortalama 2.3 yıl süreyle ellerinde tutuklarını ifade etmişlerdir. Bir dişi kazdan yılda ortalama 4.34 adet yumurta ve 2.36 adet civciv alındığı belirlenmiştir.

Yılda 0-25 adet kaz üreten yetiştiricilerin oranı \%42; 26-50 adet üretenlerin oranı \%13.6; 5175 adet üretenlerin oranı \%24.7; 76-100 adet üretenlerin oranı $\% 6.2$ ve 101 adet ve daha fazla üretenlerin oranı ise \%1.2 olarak saptanmıştır. Yetiştiricilerin \%57.6'sı, doğal kuluçkada bir kazın altına yaklaşık 8-9 adet yumurta bıraktıklarını ifade etmişlerdir.

\section{Kaz barınaklarının yapısal durumu}

Anket sonuçlarına göre, kaz barınaklarının büyüklüğünün $6 \mathrm{~m}^{2}$ ile $100 \mathrm{~m}^{2}$ arasında değiştiği ve ortalama olarak $50 \mathrm{~m}^{2}$ olduğu belirlenmiştir. Barınaklarının \%46'sının briket, \%27'sinin tahta, $\% 18$ 'inin betonarme, $\% 7^{\prime} \operatorname{sinin}$ taş ve $\% 2$ 'sinin ise kerpiç malzemesinden yapıldığı tespit edilmiştir. Barınakların \%70'inde çatı malzemesi olarak sac, $\% 13^{\prime}$ ünde toprak, $\% 12$ 'sinde beton, $\% 5^{\prime}$ inde ise tahta kullanıldığı saptanmıştır. Bir veya daha fazla penceresi olan barınakların oranı \%82, penceresi olmayan barınakların oranı ise $\% 25$ olarak tespit edilmiştir.

Barınakların \%66'sında tepsi veya tabak şeklinde, \%21'inde ise yuvarlak plastik şeklinde yemlikler kullanıldığı \%13'ünde ise hiç yemlik kullanmadığı gözlenmiştir. Barınaklarda kullanılan suluk tiplerinin, \%47'sinin tepsi veya tabak, \%34'ünün teneke, \%18'inin yuvarlak plastik ve $\% 1$ 'inin oluk şeklinde olduğu belirlenmiştir. Barınakların, \%53'ünde zemine altlık olarak saman, $\% 11^{\prime}$ inde talaş ve $\% 5^{\prime}$ inde ise odun külü serildiği belirlenirken, \%31'inde altlık serilmediği saptanmıştır. Yetiştiricilerin \%77'si kışın kümesi havalandırdıklarını, \%23'ü ise havalandırmadıklarını ifade etmişlerdir.

Barınaklarda duvar yüksekliğine bakıldığında, barınakların \%99'unda $1.5 \mathrm{~m}$ ve üzerinde olduğu gözlenmiştir. Boz ve ark., (2014), Yozgat ilinde yaptıkları bir çalışmada, kazların genellikle diğer hayvanlarla birlikte aynı barınakta barındırıldığını ve barınaklarda ekipman (folluk, yemlik, suluk) kullanılma oranının ise \%38 düzeyinde olduğunu bildirmişlerdir. Diğer bir çalışmada, Boz ve ark., (2016) Samsun'da ilinde kaz yetiştirilen kümeslerde altlık malzemesi olarak talaş kullanıldığını bildirmişlerdir.

\section{Kazların bakım ve beslemeleri}

Incelenen işletmelerde kaz yetiştiriciliğine dair bakım ve besleme uygulamaları Çizelge 1'de verilmiştir.

Kazların, genellikle sabah erken saatlerde dışarı çıkarıldıkları; palazları meraya çıkarma yaşının 4 hafta olduğu; kazların genellikle çayırlarda otlatıldığı ve içerde iken daha çok tahıllarla (buğday, arpa ve mısır) beslendiği belirlenmiştir. Yetiştiricilerin, yemleri genellikle köyden satın aldığı ve kazlara sabah-akşam olmak üzere günde $2 \mathrm{kez}$ veya düzensiz yemleme yapıldığı saptanmıştır. Ticari yem kullanma oranının \%14.3 gibi oldukça düşük bir düzeyde olduğu görülmüştür. Kırmızıbayrak ve ark., (2011) tarafından Kars'ta yapılan çalışmada, kazların beslemesinin kesimden 1-1.5 ay öncesine kadar tamamen meraya bağlı olduğu, son dönemde ise kesif yemle ya da arpa kırmasıyla besleme yapıldığı bildirilmiştir. Yozgat ilinde yapılan bir çalışmada, kazların mera, otlak, köy alanı ve su kenarlarında otladığı, bunun yanı sıra tahıllar ev artıkları ve diğer hayvanlar için kullanılan ticari yemlerle ek yemleme yapıldığı, en fazla kullanılan yemlerin ise tahıl ve ev artıkları olduğu belirlenmiştir (Boz ve ark., (2014). Sarıca ve ark., (2015)'nin Yozgat'ta yapmış oldukları diğer bir çalışmada, kazların 3 haftalık yaştan kesime kadar merada otlatıldığı, mera dönüşünden sonra ise buğday, arpa ve ev artıkları ile yemleme yapıldığı bildirilmiştir.

Kazların, diğer kanatlı hayvanlarla oranla hastalıklara karşı çok daha dirençli olduğu bildirilmiştir (Kırmızıbayrak, 2001; Labatut, 2002; Ünal ve ark., 2005; Sarıca ve ark., 2015; Karabulut ve ark., 2017). Bu nedenle, hastalıklara karşı hiçbir önlem alınmaması veya alınan önlemlerin yetersiz olması durumunda bile, kazlarda ölüm oranı düşüktür. Anket sonuçlarına göre, yetiştiricilerin büyük bir kısmının (\%67) hastalıklara karşı hiçbir önlem almadığı belirlenirken, \%30'unun vitamin, ilaç vb. kullanarak, \%3'ünün ise aşı yaparak önlem aldığı saptanmıştır. Yetiştiricilerin \%85'i her yıl 
kazlarının çok az bir kısmının, \%15'i ise yarıdan azının öldüğünü ifade etmişlerdir. Demir ve ark., (2013), Ardahan'da yaptıkları bir çalışmada, kazların ölüm oranını \%13; Demir ve Aksu Elmalı (2012) ise, Kars'ta yaptıkları çalışmada \%8.7 olarak saptamışlardır. Yozgat'ta yapılan çalışmada, kazlarda hastalık görülme oranının \%1.5 gibi düşük bir oran olduğu belirlenmiştir (Boz ve ark., 2014). Taşkın ve ark., (2017), Kırşehir ilinde, kazların hastalıklara karşı dayanıklı olmasının yetiştiriciler açısından önemli bir avantaj olarak görüldüğünü bildirmişlerdir.

İncelenen işletmelerde, kazların bakım ve beslenmesinin $\% 77$ oranında bütün aile bireyleri tarafından yapıldığı belirlenmiştir. Demir ve ark., (2013) tarafından yapılan çalışmada, kazların yetiştirilmesiyle genellikle yöredeki ev hanımlarının ilgilendiği bildirilmiştir.

Çizelge 1. Inncelenen işletmelerdeki kazların bakım ve beslenmesi ile ilgili bilgiler

\begin{tabular}{|c|c|}
\hline Bakım-besleme & Oran (\%) \\
\hline \multicolumn{2}{|l|}{ Kazların dışarı çıkma zamanı, } \\
\hline Sabah erken & 69.5 \\
\hline Öğlene doğru & 7.6 \\
\hline Her ikisi de & 22.9 \\
\hline \multicolumn{2}{|l|}{ Meraya otlatmaya çıkarma yaşı*, } \\
\hline 2 haftalık & 6.8 \\
\hline 3 haftalık & 20.4 \\
\hline 4 haftalık & 66.7 \\
\hline 5 haftalık & 20.0 \\
\hline 6 haftalık & 1.9 \\
\hline \multicolumn{2}{|l|}{ Kazların otlatıldığı yer, } \\
\hline Anızda & 2.9 \\
\hline Çayırda & 89.5 \\
\hline Su kenarında & 7.6 \\
\hline \multicolumn{2}{|l|}{ Kazların beslendiği yem çeşidi, } \\
\hline Tahıllar & 72.4 \\
\hline Ticari yem & 14.3 \\
\hline Yemek artıkları & 13.3 \\
\hline \multicolumn{2}{|l|}{ Yemlerin temin edilme durumu, } \\
\hline Kendi üretiyor & 15.2 \\
\hline Köyden satın alıyor & 61.0 \\
\hline il veya ilçe merkezinden satın alıyor & 23.8 \\
\hline \multicolumn{2}{|l|}{ Kazların günlük yemleme sayısı, } \\
\hline Günde 1 defa & 11.4 \\
\hline Günde 2 defa & 46.7 \\
\hline Günde 3 defa & 4.8 \\
\hline Diğer (düzensiz) & 37.1 \\
\hline
\end{tabular}

*Birden fazla seçenek işaretlenmiştir.

\section{Yetiştirilen kazların pazarlanması}

Incelenen işletmelerde, büyütülen kazların

$\% 55.2$ oranında il merkezinde, $\% 44.8$ oranında ise köyde satıldığı belirlenmiştir. Kazların genelde canlı olarak satıldığı, ancak az da olsa kesilmiş ve temizlenmiş olarak ta satıldığı saptanmıştır. Satış fiyatlarına bakıldığında, ortalama olarak erkek kazın 124.0 TL'den, dişi kazın ise 99.0 TL'den satıldığı belirlenmiştir. Kazların, yoğun olarak Kasım (\%37) ve Aralık (\%63) aylarında satıldığı saptanmıştır. Yetiştiricilerin tamamı, kuluçkadan çıkan kazların \%90'ından fazlasının satışa kadar canlı kaldığını ifade etmişlerdir. Demir ve ark., (2013) tarafından yürütülen çalışmada, yetiştiricilerin ellerinde bulunan kazların ya kesip temizledikten sonra ya da canlı olarak ortalama 78.43 TL'ye ve satıldığı belirlenmiştir. Yetiştiricilerin ürettikleri kazların satış yerinin farklılıklar gösterdiğini tespit eden Taşkın ve ark., (2017) yaptıkları çalışmada, en önemli satış yerinin pazar yeri olduğunu (\%40), $\% 25^{\prime}$ inin tüccara ve $\% 15^{\prime}$ inin yakın çevreye satıldığını bildirmişlerdir.

\section{Üreticilerin kaz yetiştiriciliği hakkındaki düşünceleri}

Çalışmada, yetiştiricilerin \%95.2'si, kazları için kümeslerine konuyla ilgili herhangi bir uzmanın gelmediğini, \%4.8'i ise yılda bir kez geldiğini belirtmişlerdir. Bunun yanı sıra, yetiştiricilerin tamamına yakını (\%98) kaz yetiştiriciliğine devam etmek istediklerini ifade etmişlerdir. Yine, yetiştiricilerin tamamına yakınının (\%97) kaz 
yetiştiriciliğini devlet desteği almadan yürüttükleri belirlenmiştir. Kaz yetiştiriciliğini karlı bir iş olarak görenlerin oranı \%68.7, karlı görmeyenlerin oranı ise \%31.3 olarak tespit edilmiştir. İşletmelerin büyük bir kısmında (\%98) yerli ırk kazlarla yetiştiricilik yapıldığı, az sayıdaki işletmede ise yabancı ırklarla veya karışık (yerli-yabancı) olarak üretim yapıldığı belirlenmiştir.

Kaz yetiştiriciliği ile ilgili sorunlarınız nedir? sorusuna cevap veren yetiştiriciler, genellikle palaz temini, yem gideri, ilaç-aşı ve veteriner hizmetleri konularındaki desteklerin çok yetersiz olduğunu ve pazarlamayla ilgili önemli sorunları olduğunu ifade etmişlerdir. Ardahan'da, Demir ve ark., (2013) tarafından yapılan bir çalışmada, kaz yetiştiriciliğinin zorlukları, yem fiyatlarının yüksek olması, kuluçka veriminin düşük olması ve bakımlarının uzun sürmesi olarak tespit edilmiştir. Kaz yetiştiriciliğinin bölgede gelişmesi için yetiştiricilerin özellikle konuya yönelik eğitim ve devlet desteği verilmesinin gerekli olduğunu ifade ettikleri bildirilmiştir. Boz ve ark., (2014) tarafından Yozgat ilinde yapılan çalışmada, yöre halkının kaz yetiştiriciliğinde sorun olarak gördüğü konular; bakım-besleme konusundaki bilgi eksikliği, devlet desteği yetersizliği ve düşük verimli ırklarla üretim yapma şeklinde sıralanmıştır.

\section{Sonuç ve Öneriler}

Muş ilinde yapılan kaz yetiştiriciliğinin, genelde kırsal kesimdeki ailelerin geleneksel olarak et ihtiyacını karşılamak amacıyla yapılan bir aile işletmeciliği olduğu saptanmıştır. Gerek üretim amacı ve üretim şekli, gerekse yapısal sorunları ve pazarlama problemleri bakımından ülke genelindeki kaz yetiştiriciliğinin yapısıyla önemli benzerlikler göstermektedir. Yetiştiriciler, genellikle az sayıda hayvanla, bölgeye uyum sağlamış fakat düşük verimli ırklarla üretim yapmaktadırlar. Üreticilerin önemli bir kısmı palaz satın alarak üretim yapmakta olduğundan, gerek palaz teminindeki zorluklar ve gerekse yüksek palaz fiyatları üretimi sınırlandırmaktadır. Kaz barınaklarının durumu ve bakım-besleme konusundaki yetersizlikler verimlerdeki düşüklüğün nedenleri arasındadır. Yetiştiricilerin, sağlık-koruma ve hastalıklar konusunda hiçbir önlem almaması da karlılığı azaltan önemli sorunlarından biridir. Diğer dikkati çeken önemli bir sorun da, pazarlama ve satış konusunda yaşanan problemlerdir. Gerek, pazar bulmadaki zorluklar ve gerekse kazların değer fiyattan satılamaması üretimi sınırlayan önemli sorunlardır. Yetiştiricilerin, daha büyük kapasite ile üretim yapması konusunda devletin teşvik ve desteği yetersizdir. Tüm bu olumsuzluklara rağmen, üreticilerin kaz yetiştiriciliğini sürdürme isteğinin yüksek olması ümit verici bir durumdur.
Yetiştiricilerin başlıca sorunlarının; palaz teminindeki zorluklar, palaz ve yem fiyatlarının yüksekliği, düşük verimli ırklar, yetersiz bakımbesleme, yetersiz veteriner hizmetleri, yüksek ölüm oranı, yetersiz devlet desteği ve pazarlamada karşılaşılan problemler olduğu belirlenmiştir. Muş ilindeki kaz yetiştiriciliğinin geliştirilmesine katkı sağlamak amacıyla aşağıda bazı önerilere yer verilmiştir:

Kaz yetiştiriciliği, yöre halkı için alternatif bir gelir kaynağı olarak görülmelidir. Kaz yetiştiriciliğinin, modern üretim sistemleri kullanılarak, teknik ve rasyonel uygulamalarla daha karlı hale getirilmesi sağlanmalıdır. Bu konuyla ilgili olarak, üreticilere eğitim seminerleri verilmeli ve geleneksel üretim şeklinin zamanla yarı entansif ve entansif üretime dönüşmesi teşvik edilmelidir. Üreticilerin ihtiyacı olan kaliteli ve yüksek verimli damızlık palazlar devlet tarafından temin edilip, üreticiye ücretsiz olarak dağıtılmalıdır. Kaz üretimini geliştirmek için, üreticilere, barınak, kuluçka makinası, ekipman vb. yatırımlar için, belirli bir kısmı hibe olmak üzere, uzun vadeli ve faizsiz krediler verilmelidir. Yörede, sanayicilere verilecek teşviklerle modern bir adet kaz kuluçkahanesi ve bir adet kaz kesimhanesinin kurulması bu konuda çok önemli bir adım olacaktır. Kurulacak kesimhane ile, bölgede üretilen kazların sağlıklı bir şekilde kesimi, paketlenmesi ve muhafazası sağlanacak ve çok değerli bir kaz ürünü olan kaz tüylerinin değerlendirilmesi mümkün olabilecektir. Ayrıca, kurulacak olan kesimhanenin sağlayacağı avantajlardan yararlanmak amacıyla, sözleşmeli yetiştiricilik uygulaması başlatılmalı ve modern kaz yetiştiriciliği teşvik edilmelidir. Üretime yönelik uygulamaların dışında, uygun iç ve dış pazar alt yapısının oluşturulması da büyük önem arz etmektedir.

§: Bu çalışma İsmail YETER'in Prof. Dr. Turgay ŞENGÜL'ün danışmanlığında yürütmüş olduğu yüksek lisans tezinden üretilmiştir.

\section{Kaynaklar}

Aksoy, T., Arıkan, F. 1995. Tekirdağ bölgesinde yetiştirilen kazlarda kesim sonuçlarına ilişkin bir araştırma. Hayvancılık 96 Ulusal Kongresi, 18-20 Eylül, İzmir.

Aygün, G., Akbulak, C. 2017. Ardahan ili organik hayvancılık potansiyelinin değerlendirilmesi. Dumlupınar Üniversitesi Sosyal Bilimler Dergisi, 53: 144-161.

Boz, M.A., Sarıca, M., Yamak, U.S. 2014. Yozgat İlinde kaz yetiştiriciliği. Tavukçuluk Araştırma Dergisi, 11(1): 16-20.

Boz, M.A., Sarıca, M., Yamak, U.S., 2016. Kapalı ve serbest gezinmeli üretim sistemlerinde doğal 
ve yapay kuluçka ile üretilen kazların ekonomik değerlendirmesi. Türk Tarım-Gıda Bilim ve Teknoloji Dergisi, 4(11): 981-986.

Cywa- Benko, K., Wezyk, S., Krawczyk, J., Knapik, J., Bielinska, H., Rosinski, A. 1999. The possibility of using Usg technique for muscle and fatness testing in geese. $12^{\text {th }}$ European Symposium on Waterfowl, Adana, Turkey.

Çelebi, S. 1999. Erzurum'da yetiştirilen kazların bazı önemli kesim ve karkas özellikleri üzerine bir araştırma. Uluslararası Hayvancılık'99 kongresi, 21-24 Eylül, İzmir.

Çelik, B. 2007. Muş yöresi yerli kazlarında kesim ve karkas özellikleri. Kocatepe Üniversitesi, Sağlık Bilimleri Enstitüsü, Zootekni Anabilim Dalı Yüksek Lisans Tezi, Afyon.

Çelik, B. Bozkurt, Z., 2009. Muş yöresi yerli kazlarında kesim ve karkas özellikleri. Lalahan Hay. Araşt. Enst. Derg. 49: 37-46.

Demir, P., Aksu Elmalı, D. 2012. Economical analysis of goose breeding commercially by small family farms. World's Poultry Science Journal, 68: 5-10.

Demir, P., Kırmızıbayrak, T., Yazıcı, K. 2013. Kaz yetiştiriciliğinin sosyo-ekonomik önemi. Ankara Üniversitesi Veteriner Fakültesi Dergisi, 60: 129-134.

Karabulut, O., Ün, H., Çamkerten, İ., Garip, M., Bulut, G. 2017. Aksaray yöresi kazlarda kuluçka randımanı üzerine araştırmalar. Bahri Dağdaş Hayvancılık Araştırma Dergisi Journal of Bahri Dagdas Animal Research 6(1): 13-22.

Karasar, N. 1994. Bilimsel araştırma yöntemi: Kavramlar, İlkeler, Teknikler. ISBN 975-95432-1-6, Ankara.

Kırmızıbayrak, T. 2001. Kars ilinde kaz yetiştiriciliği ve ekonomik önemi. Çiftlik Derg., 206: 62-64.

Kırmızıbayrak, T. Önk, K., Yazıcı, K. 2011. Kars ilinde serbest çiftlik koşullarında yetiştirilmiş yerli ırk kazların kesim ve karkas özellikleri üzerine yaş ve cinsiyetin etkisi. Kafkas Univ. Vet. Fak. Derg. 17: 41-45.

Labatut, M.C. 2002. Goose production in Chile and South America. Eds: Buckland R and Guy G: Goose Production. FAO Animal Production and Health paper No: 154, Rome, Italy.

Sarıca, M., Boz, M.A., Yamak, U.S. 2015. Yozgat ili halk elinde yetiştirilen Beyaz ve Alaca kazların kesim ve karkas özellikleri. Türk Tarım-Gıda Bilim ve Teknoloji Derg., 3(3): 142-147.

Taşkın, A., Karadavut, U., Camcı, Ö. 2017. Kırşehir ilindeki damızlık kaz yetiştiriciliğini etkileyen faktörlerin belirlenmesi. Türk Tarım ve Doğa Bilimleri Dergisi 4(2): 138-144.
TÜik, 2018. Veri tabanları, www.tuik.gov.tr (Erişim tarihi: 15.03.2019).

Ünal, Y., Kaya, İ., Saatçi, M., Yıldız, S., Öncüer, A. 2005. Farklı protein düzeylerinde beslemenin kazlarda besi performansına etkisi. Lalahan Hay. Araşt. Enst. Derg. 45: 3339. 